\title{
Keefektifan Teknik Expressive Writting untuk Mereduksi Emosi Negatif Siswa SMA
}

\author{
Septin Anggraini ${ }^{1}$, Imanuel Hitipeuw ${ }^{1}$, Andi Mappiare ${ }^{1}$ \\ ${ }^{1}$ Bimbingan dan Konseling-Universitas Negeri Malang
}

\begin{tabular}{l}
\hline INFO ARTIKEL \\
\hline Riwayat Artikel: \\
Diterima: $19-11-2018$ \\
Disetujui: $16-01-2019$ \\
\hline
\end{tabular}

\section{Kata kunci:}

expressive writing; negative emotions; high school student; expressive writing; emosi negatif; siswa SMA

\author{
Alamat Korespondensi: \\ Septin Anggraini \\ Bimbingan dan Konseling \\ Universitas Negeri Malang \\ Jalan Semarang 5 Malang 65145 \\ E-mail: Sefty943@gmail.com
}

\begin{abstract}
ABSTRAK
Abstract: Negative emotion is unpleasant circumstances so affect the attitudes and behavior of individuals in interacting with others. As for the negative emotions are emotions angry, anxious and sad. Of the phenomenon required the efforts of guidance to channel the emotion that is by counselling techniques expressive writting on the students. This research is to know the level of negative emotions of students by using survey data. This research uses data collection inventory, interview equipped observation sheets. As for the subject researches are students in 10 Wretched SMAN. On the results of research counselor counseling application well welcomed by the technique of expressive and showed the attitude of students writting enthusiastic in following counselling techniques expressive writting.

Abstrak: Emosi negatif merupakan keadaan kurang menyenangkan yang memengaruhi sikap dan perilaku individu dalam berinteraksi dengan orang-orang yang ada di sekitarnya. Adapun emosi negatif adalah rasa marah, cemas, dan sedih. Dari fenomena tersebut diperlukan upaya bimbingan untuk menyalurkan emosi yaitu dengan konseling teknik expressive writting pada siswa. Penelitian ini untuk mengetahui tingkat emosi negatif siswa dengan menggunakan data survei. Pengumpulan data penelitian ini menggunakan inventory, wawancara yang dilengkapi lembar observasi. Adapun subjek penelitian adalah siswa di SMAN 10 Malang. Pada hasil penelitian konselor menyambut dengan baik penerapan konseling dengan teknik expressive writting dan siswa menunjukkan sikap antusias dalam mengikuti konseling teknik expressive writting.
\end{abstract}

Penelitian ini berlatar belakang berdasarkan fenomena yang terjadi pada siswa-siswi yang memiliki emosi negatif. Emosi negatif tersebut mencakup meningkatnya emosi marah, sedih, dan cemas. Berbagai bukti yang ada dalam studi pendahuluan, media masa menunjukkan bahwa tingkat emosi marah cenderung lebih tinggi dari pada tingkat kesedihan dan kecemasan yang dialami oleh siswa SMA. Tingkat emosi negatif yang tinggi ini menjadi fenomena yang terjadi di masyarakat khususnya terjadi pada para remaja yang belum dapat mengendalikan emosi negatif dengan baik sehingga mereka menyalurkan emosi dengan cara tidak tepat. Rendahnya untuk mengendalikan emosi negatif siswa tersebut merupakan salah satu penyebab meningkatnya emosi marah pada siswa karena dengan tingkat kemarahan siswa yang cenderung lebih tinggi dari pada tingkat kesedihan dan kecemasan memengaruhi komunikasi dengan orang lain dan perilaku siswa dan merugikan orang lain dan diri sendiri ketika mereka tidak dapat mengendalikan dengan cara yang tepat.

Kesadaran dalam menyelesaikan konflik secara konstruktif ini merupakan salah satu penyebab bagi timbulnya kekerasan karena dibalik terjadinya kekerasan terdapat konflik yang belum terselesaikan dengan baik. Marah merupakan suatu keadaan seseorang yang menyalahkan orang lain, diri sendiri dengan suatu penyebab tertentu. Emosi marah ini cenderung ditandai dengan raut muka memerah, nada suara keras, dan otot-otot tangan menegang. Kecemasan merupakan suatu keadaan yang muncul dari diri seseorang karena menunggu sesuatu yang belum pasti. Reaksi seseorang ketika sedang cemas yaitu dengan mengepalkan tangan, tampak bingung, dan gemetar. Kesedihan itu sendiri merupakan suatu keadaan seseorang dimana mereka mengalami kegagalan dalam mencapai tujuan, kehilangan seseorang yang dicintainya. Namun, reaksi yang terlihat ini cenderung lebih menyendiri, merenung, menangis dan menarik diri dari kegiatan di sekolah (Lazarus, 1991).

Untuk menyalurkan emosi negatif siswa perlu dilaksanakan konseling dengan menggunakan teknik expressive writting. Didalam teknik konseling expressive writing ini banyak terdapat keterampilan yang dapat menunjang proses konseling khususnya untuk siswa yang sulit mengungkapkan pikiran atau perasaannya melalui bercerita atau berbicara dengan konselor Teknik expressive writing termasuk bagian dari terapi ekspresif yang berfokus pada emosi. Dimana terjadi pelepasan emosi 
melalui tulisan dan dapat meningkatkan pengalaman baru pada individu. Teknik expressive writing merupakan sebuah upaya atau cara dengan menggunakan aktivitas menulis sebagai sarana untuk merefleksikan pikiran dan perasaan terdalam terhadap peristiwa yang tidak menyenangkan ke dalam bentuk lambang bahasa melalui tulisan tangan (Pennebeker, 2004).

Tingkat kemarahan, kesedihan, dan kecemasan yang dialami oleh siswa SMA tersebut jika tidak dapat mengelola dengan baik atau mengendalikannya akan dapat merugikan diri sendiri dan orang lain. Sehingga dapat memicu suatu tindakan yang tidak diinginkan, misalnya berkelahi dengan teman, kebut-kebutan motor dengan cara yang tidak tepat. Penyaluran tingkat kemarahan inilah yang sekarang menjadi fenomena pada remaja. Para remaja menganggap bahwa dengan berkelahi dengan teman, kebut-kebutan motor di jalan dapat membuat diri remaja yaitu siswa SMA merasa lega karena sudah menyalurkan kemarahannya. Sebagian besar siswa SMA ini cenderung lebih tertutup kepada konselor dan teman-temannya untuk menceritakan hala apa saja yang dialami ketika mereka memiliki masalah, sama halnya ketika mereka mengalami kecemasan. Dengan sikap siswa tersebut teknik expressive writing ini mulai diterapkan dalam bimbingan dan konseling di SMA 10 Malang. Tanpa disadari bahwa dengan sikap mereka seperti itu akan sangat menganggu proses mengikuti pelajaran dikelas. Pada dasarnya periode perkembangan anak SMA dapat dikategorikan dimana individu berkembang dan mengatur emosi untuk mengelola keadaan. Sedangkan pada anak usia remaja ini dapat dikatakan emosi cenderung masih labil dan sangat sensitif dalam hal perasaan sehingga banyak diwarnai oleh berbagai emosi (Desmita, 2005).

Pengelolaan emosi itu sangat berperan penting dalam diri remaja, mencapai kemandirian emosional dimaan remaja harus mampu mengelola emosi dengan baik dan menyalurkannya dengan cara yang tepat (Hurlock, 1999). Remaja memiliki tuntutan untuk dapat memiliki pola pikir dalam memecahkan masalahnya baik pribadi maupun sosial. Proses kemunculan emosi negatif pada remaja melibatkan faktor psikologis maupun faktor fisiologis. Diantara perkembangan yang dialami oleh remaja ialah perkembangan intelegensi, emosi, sosial, dan moral (Santrock, 2007). Barry \& Singer (2001) menyatakan bahwa expressive writing tidak membutuhkan biaya yang mahal dan waktu yang panjang seperti psikoterapi sehingga dapat digunakan berbagai kalangan subjek termasuk siswa SMA Negeri 10 Malang.

Remaja yang memiliki tingkat kemarahan, kecemasan, dan kesedihan ini memiliki karakteristik (a) emosinya tidak dapat diprediksikan munculnya emosi negatif remaja tidak dapat direncanakan karena emosi muncul ketika perasaan remaja tidak menentu, (b) sulit dikendalikan, remaja cenderung sulit mengontrol emosi sehingga remaja menyalurkan emosi negatifnya dengan cara yang kurang tepat, (c) sensitif berlebihan suatu keadaan yang sebagian besar dimiliki oleh diri remaja dengan bersikap berlebihan ketika munculnya emosi, (d) tidak ada ketetapan, kondisi remaja yang tidak selalu mempersepsikan suatu hal dengan baik, (e) adanya ketidaktepatan dalam mempersepsikan diri sendiri atau lingkungan remaja cenderung mempersepsikan keadaan yang terjadi di lingkungan secara berlebihan.

Goleman (2007) menyatakan bahwa ada empat ciri-ciri reaksi emosi negatif yang dialami oleh setiap orang, yaitu (a) psikologis, (b) fisiologis, (c) proses berpikir (kognitif), dan (d) tingkah laku, seperti menghindar bertemu dengan temannya, membolos saat sekolah, jahil atau suka mengganggu, merokok, berkelahi dengan temannya. Emosi negatif cenderung dapat dilihat dari aspek nonverbal konseli, seperti ekspresi terkejut, raut mimik dan vokal, sikap dan gerak tubuh, perubahan fisiologis dan tindakan-tindakan emosional. Ketika konseli sedang mengalami emosi marah, maka orang lain di sekitar dapat melihat secara nonverbal, melalui tindakan, wajah memerah dan vokal. Namun, yang sering terjadi konseli ini cenderung lebih ke aspek verbal, seperti memaki-maki, memukul dan berteriak kepada temannya jika ia merasa tersinggung dengan ucapan teman. Dari kedua aspek tersebut dapat dilihat ketika perilaku konseli mengekspresikan emosi negatif dengan cara verbal atau nonverbal.

Mengelola emosi memiliki peranan penting yaitu pada tingkat kemarahan, sedih dan cemas sehingga remaja tersebut dapat mengontrol emosi dan menyalurkan emosinya dengan cara yang tepat. Ketika remaja menyalurkan emosi negatifnya dengan cara yang tepat, tidak akan merugikan diri sendiri dan orang lain di sekitar. Tingkat kemarahan remaja lebih besar, tidak dapat dipungkiri bahwa marah merupakan suatu keadaan emosi yang dimiliki oleh setiap manusia. Namun, dengan adanya penerapan teknik expressive writing ini siswa yang mengalami emosi negatif, mereka lebih mengekspresikan dengan cara menulis sebagai ungkapan perasaan yang dialaminya (Paez, 1999). Pada dasarnya dengan penerapan tkonseling dengan teknik expressive writing ini memiliki manfaat untuk siswa dalam menyalurkan perasaanya dan dapat digunakan oleh konselor dalam mengatasi masalah yang berkaitan dengan emosi negatif.

\section{METODE}

Penelitian ini menggunakan penelitian eksperimen dengan menggunakan rancangan penelitian Single-Subject Design Shaughnessy, dkk (2012) menyatakan bahwa single-subject design merupakan rancangan yang fokusnya untuk mengevaluasi perubahan perilaku individu. Tipe yang digunakan dalam penelitian ini adalah multiple baseline. Tipe multiple baseline ini merupakan bagian dari single subject research design. Penelitian ini rancangan yang digunakan adalah multiple baseline across subject. Rancangan multiple baseline across subject digunakan karena dalam penelitian ini memberikan treatment kepada beberapa subjek dengan tujuan perubahan dan setting yang sama. Dari dampak intervensi didemontrasikan dengan mengenalkan suatu intervensi dalam baseline yang berbeda pada waktu yang berbeda (Kazdin, 1982). 


\section{Instrumen Pengumpulan Data}

Pengumpulan data penelitian berupa inventori emosi negatif. Tujuaannya adalah untuk mengukur tingkat emosi negatif pada siswa. Bentuk inventori emosi negatif berupa format yang dipakai adalah sangat setuju, setuju, tidak setuju, dan sangat tidak setuju. Inventori emosi negatif digunakan untuk menjaring siswa yang memiliki emosi negatif sebagai alat ukur untuk purpose sampling. Adapun adaptasi dan pengembangan dalam perosedur ini sesuai dengan tujuan suatu penelitian yang berupaya untuk mengetahui prosedur yang akan digunakan sesuai dengan tujuan penelitian yang berupaya untuk mengetahui suatu tingkat kebutuhan siswa terhadap konseling expressive writting untuk mereduksi emosi negatif. Penelitian ini dilaksanakan di SMAN 10 Malang dengan tiga subjek.

\section{Analisis Data}

Penelitian ini menggunakan rancangan eksperimen Single Subject Research Design dengan tipe Multiple Baseline Across Subject adalah analisis data visual. Analisis data visual adalah membaca grafik untuk menentukan apakah intervensi telah menunjukkan perubahan pada kondisi sebelum intervensi. Dalam penelitian ini, analisis data visual dilakukan untuk mengetahui perubahan yang terjadi setelah dilaksanakan intervensi. Terdapat tiga hal yang harus diperhatikan dalam melakukan analisis data visual adalah trend, level, dan variabilitas (Engel \& Schutt, 2005). Untuk kriteria dalam melakukan analisis data visual dengan memperhatikan level, tren, dan variabilitas. Analisis data visual ini dilakukan secara individual, dilakukan dengan menstabulasikan hasil pengukuran dan menggambarkannya dalam grafik replikasi, dimana hasil pengukuran pada tahap baseline dan intervensi pada setiap subjek penelitian akan dilakukan analisis. Hal ini dilakukan untuk mendapatkan gambaran yang lebih lengkap tentang hasil penelitian.

\section{HASIL DAN PEMBAHASAN}

Teknik konseling expressive writting yaitu merupakan hal yang penting untuk dikembangkan oleh peneliti. Dilakukanya penelitian awal dapat menjadikan dasar yang kuat sebagai bukti dan terhadap bentuk kebutuhan siswa akan penerapan teknik expressive writing untuk menyalurkan segala emosi yang mereka alami. Adapun pengumpulan data kebutuhan untuk siswa tersebut dilakukan menggunakan inventori dan wawancara dengan konselor serta dilengkapi dengan pengamatan secara langsung oleh observer.

Hasil penelitian menunjukkan bahwa siswa di SMAN 10 Malang memahami dan menerapkan pentingnya penyaluran emosi dengan cara yang tepat dan dapat mengontrol emosi. Dalam penerapan konseling teknik expressive writting peneliti atau konselor dapat memberikan layanan bimbingan dan konseling kepada siswa. Proses layanan konseling, observer tidak memiliki perbedaan saat memberikan layanan konseling pada siswa yang memiliki emosi negatif tersebut. Pelaksanaan dilakukan sama, namun dengan setting yang berbeda, sedangkan tahap yang dilakukan untuk memberikan treatment ini sama. Sehingga konselor dapat menerapkan konseling dengan teknik expressive writting untuk siswa yang memiliki masalah emosi negatif.

Siswa di SMAN 10 Malang menyadari dengan baik terhadap teknik konseling expressive writting. Pada dasarnya menggunakan teknik konseling expressive writting dalam pemberian layanan konseling kepada seluruh siswa, termasuk pada siswa yang memiliki emosi negatif. Adapun pengembangan teknik konseling expressive writting, dengan adanya penerapan tersebut konselor menyambut baik dan mendukung adanya penerapan teknik konseling expressive writting.

Terdapat hasil analisis dari inventori serta wawancara yang menemukan bahwa bentuk dari teknik konseling expressive writting untuk mereduksi emosi negatif sesuai dengan kebutuhan siswa di SMAN 10 Malang, bahwa teknik konseling expressive writting diharapkan memberikan manfaat yang baik untuk siswa dalam menyalurkan emosinya dan memiliki karakteristik, seperti (1) memiliki dasar teoritik; (2) mudah untuk dipelajari dan digunakan oleh konselor; (3) pemaparan materi dan cara pengimplementasian yang jelas; (4) efektif dan efisien dalam pelaksanaannya.

Kemudian teknik konseling expressive writing yang dikembangkan ini dapat digunakan dalam bentuk skenario untuk dipelajari dan diterapkan oleh konselor dalam proses pemberian layanan konseling kepada siswa yang memiliki emosi negatif. Kebutuhan konselor terhadap skenario ini sesuai dengan kebutuhan yang terdapat dilapangan, berdasarkan hasil penelitian yang memiliki sebuah isi secara rasional, tujuan konseling yang akan dicapai, langkah-langkah yang digunakan dalam proses konseling expressive writting dan evaluasi pelaksanaan konseling. Hasil penelitian berlanjut pada proses penyusunan kerangka teknik konseling expressive writting yang memberikan gambaran adanya tahapan pelaksanaan teknik konseling expressive writing sebagai berikut.

Pertama, rasional prosedur. Tahap pertama ini bertujuan untuk memperoleh data tentang kondisi seorang konseli yang akan ditangani leih lanjut oleh konselor serta mampu mengantisipasi kemungkinan kesalahan dalam penanganan pada proses konseling. Pada tahap ini terdapat beberapa kegiatan yang akan dilaksanakan (a) penyebaran alat ukur (inventori) untuk pengumpulan informasi konseli dan (b) melakukan kontrak konseling dengan konseli agar konseli mampu berkomitmen dalam mengikuti setiap sesi pada proses konseling dari tahap awal sampai tahap akhir.

Kedua, Recognation/initial writing. Tahap ini merupakan tahap pembuka yang berisi kegiatan membangun kenyamanan untuk menulis. Konseli diberi kesempatan untuk menulis dengan bebas kata-kata dan mengungkapkan hal lain yang muncul dalam pikiran tanpa perencanaan dan arahan. 
Ketiga, Examination/writing exercise. Tahap ini mengeksplorasi reaksi konseli terhadap suatu situasi tertentu. Cakupan topik tulisan juga dapat diperluas menjadi peristiwa yang emosional atau peristiwa spesifik yang dialami oleh individu.

Keempat, Juxtaposition/feedback. Tahap ini merupakan sarana refleksi yang mendorong pemerolehan kesadaran baru yang menginspirasi perilaku, sikap, nilai yang baru serta membuat individu memperoleh pemahaman yang lebih dalam tentang dirinya. Tahap ini siswa mendapatkan pengetahuan baru kemudian diaplikasikan dan berlanjut pada kesepakatan siswa dengan peneliti pada perubahan tingkah laku yang dilakukan dikemudian hari.

Kelima, Application to the self. Tahap terakhir ini, konseli didorong untuk mengaplikasian pengetahuan barunya dalam dunia nyata.

Keenam, pekerjaan rumah dan tindak lanjut. Pada tahap ini konselor akan mendorong siswa untuk mempraktikan prosedur expressive writting dalam situasi diluar pelatihan dengan konselor. Mendiskusikan hasil latihan terkait dengan pekerjaan rumah yang telah diberikan oleh konselor, konselor meminta konseli untuk mencatat dalam lembar tugas tentang penggunaan expressive writting, seperti siswa mengisi catatan pemikiran yang muncul dan menyusun kegiatan tindak lanjut.

\section{SIMPULAN}

Adapun yang terdapat dalam penelitian ini untuk penerapan teknik konseling expressive writting pada siswa, konselor menunjukkan dukungan yang penuh serta sambutan yang baik terhadap penelitian ini yang menerapkan teknik konseling expressive writting dan antusias siswa untuk mengikuti konseling dengan teknik expressive writting sebagai reduksi emosi negatif. Terdapat pada hasil penelitian juga bahwa dapat mengidentifikasi bentuk karakteristik dari treatment tersebut yang konselor inginkan untuk dikembangkan dan diterapkan lebih lanjut lagi.

Simpulan berdasarkan hasil penelitian bahwa terdapatnya saran-saran, pesan-pesan terhadap pihak-pihak praktisi bimbingan dan konseling dalam memenuhi sebuah kebutuhan seorang konselor dengan menerapkan teknik konseling teknik expressive writting. Selain itu, dapat dilakukan penelitian survei untuk selanjutnya mengenai kebutuhan seorang siswa untuk menyalurkan emosi dengan cara yang tepat dengan menerapkan metode menulis, yaitu teknik expressive writting.

\section{DAFTAR RUJUKAN}

Barry, L. M., \& Singer, G. H. (2001). Reducing Maternal Psychological Distress After the NICU Experience Through Journal Writing. Journal of Early Intervention, 24(4), 287-297.

Desmita. (2005). Psikologi Perkembangan. Bandung: PT Rosda Karya.

Engel, R., \& Schutt, R. (2005). The Practice of Rational Emotive Behavior Therapy. New York: Springer Publishing Company. Fikri, H. (2012). Pengaruh Menulis Pengalaman Emosional dalam Terapi Ekspresif terhadap Emosi Marah pada Remaja. Jurnal Padang: Humanitas, IX(2), 103-122.

Goleman, D. (2007). Working with Emotional Intellegence. Jakarta: PT. Gramedia Pustaka Utama.

Hurlock, E. B. (1999). Psikologi Perkembangan: Suatu Pendekatan Sepanjang Rentang Kehidupan. Jakarta: Erlangga.

Kazdin, A. E. (1982). Single-Case Research Design: Methods for Clinical and Applied Settings. New York: Oxford University Press.

Lazarus, R. S. (1991). The Self-Regulation of Emotion. Edited by Lennart Levi. Emotions: Their Parameters and Measurement. New York: Raven Press.

Páez, D., Velasco, C., \& González., J. L. (1999). Expressive writing and the role of alexythimia as a dispositional deficit in selfdisclosure and psychological health. Journal of Personality and Social Psichology, 77(33), 630 - 641.

Pennebaker, J. W. (2004). Theories, Therapis, and Taxpayers: On the Complexcities of the Expressive Writing Paradigm. Journal of Clinical Psychology: Science and Practice, 11(2), 138-142.

Piaget, J. (1983). Handbook of Child Psychology. 4th edition. Vol. 1. New York: Wiley.

Rahmawati, M. (2014). Menulis Ekspresif sebagai Strategi Mereduksi Stres untuk Anak-anak Korban Kekerasan dalam Rumah Tangga (KDRT). Jurnal Ilmiah Psikologi Terapan, 2(2), 276-293.

Santrock, J. W. (2007). Adolescence (Perkembangan Remaja). Jakarta: Penerbit Erlangga.

Shaughnessy, J. J., Zechmeister, E., \& Zechmeister, J. (2012). Metode Penelitian dalam Psikologi. (E. Tjo, Trans.) Jakarta: Penerbit Salemba Humanika.

Stroksen, I., Roysamb, E., Holmen, T. L., \& Tambs, K. (2006). Adolescent Adjustment and Well-being: Effect of Parental Divorce and Distress. Scandinavian Journal of Psychology, 47(1), 75—84. https://doi.org/10.1111/j.14679450.2006.00494.x

Warner, L. J. (2006). Health Effects of Written Emotional Disclosure in Adolescent with Asthma: A Randomized, Controlled Trial. Journal of Pediatric Psych, 31(6), 557-568. https://doi.org/10.1093/jpepsy/jsj048

Yuliani, R. (2013). Emosi Negatif Siswa Kelas XI SMA N 1 Sungai Limau. Konselor, 2(1), 151-155. 10.24036/0201321883$0-00$ 